\title{
Involvement of glutaredoxin-1 and thioredoxin-1 in $\beta$-amyloid toxicity and Alzheimer's disease
}

\author{
S Akterin ${ }^{1}$, RF Cowburn ${ }^{1}$, A Miranda-Vizuete ${ }^{2,3}$, A Jiménez ${ }^{2,4}$, \\ N Bogdanovic ${ }^{1}$, B Winblad ${ }^{1}$ and A Cedazo-Minguez ${ }^{*, 1}$ \\ 1 Section of Experimental Geriatrics, Neurotec Department, Karolinska Institutet, \\ Kliniskt Forskningscentrum (KFC), Novum, Huddinge, Sweden \\ 2 Department of Biosciences, Karolinska Institutet, Novum, Huddinge, Sweden \\ 3 Centro Andaluz de Biología del Desarrollo (CABD-CSIC), Departamento de \\ Ciencias Ambientales, Universidad Pablo de Olavide, Sevilla, Spain \\ 4 Departamento de Microbiología y Genética, CSIC/Universidad de Salamanca, \\ Campus Miguel de Unamuno, Salamanca, Spain \\ * Corresponding author: A Cedazo-Minguez, Section of Experimental Geriatrics, \\ Neurotec Department, Karolinska Institutet, Novum, KFC, plan 4, S-141 86 \\ Huddinge, Sweden. Tel: + 468585 83751; Fax: + 468585 83880; \\ E-mail: Angel.Cedazo-Minguez@.ki.se
}

Received 30.3.05; revised 17.10.05; accepted 18.10.05; published online 25.11.05 Edited by L Greene

\section{Abstract \\ Strong evidence indicates oxidative stress in the pathogen- esis of Alzheimer's disease (AD). Amyloid $\beta(A \beta)$ has been implicated in both oxidative stress mechanisms and in neuronal apoptosis. Glutaredoxin-1 (GRX1) and thioredoxin-1 (TRX1) are antioxidants that can inhibit apoptosis signal- regulating kinase (ASK1). We examined levels of GRX1 and TRX1 in AD brain as well as their effects on $A \beta$ neurotoxicity. We show an increase in GRX1 and a decrease in neuronal TRX1 in AD brains. Using SH-SY5Y cells, we demonstrate that $A \beta$ causes an oxidation of both GRX1 and TRX1, and nuclear export of Daxx, a protein downstream of ASK1. A $\beta$ toxicity was inhibited by insulin-like growth factor-I (IGF-I) and by overexpressing GRX1 or TRX1. Thus, A $\beta$ neurotoxicity might be mediated by oxidation of GRX1 or TRX1 and subsequent activation of the ASK1 cascade. Deregulation of GRX1 and TRX1 antioxidant systems could be important events in $A D$ pathogenesis. \\ Cell Death and Differentiation (2006) 13, 1454-1465. \\ doi:10.1038/sj.cdd.4401818; published online 25 November 2005}

Keywords: Alzheimer's disease; $\beta$-amyloid; glutaredoxin; thioredoxin; apoptosis; oxidative stress

\footnotetext{
Abbreviations: $\mathrm{A} \beta$, amyloid $\beta$; $\mathrm{AD}$, Alzheimer's disease; $\mathrm{AMS}$, 4-acetamido-4'-maleimidyl-stilbene-2,2'-disulfonate; ASK1, apoptosis signal-regulating kinase 1; BCA, bicinchoninic acid; CERAD, Consortium to establish a Registry for Alzheimer's disease; Daxx, death-associated protein; DSM-IV, Diagnostic and Statistical Manual of Mental Disorders-IV; DTT, dithiothreitol; ERK, extracellular signal-regulated kinase; GFAP, glial fibrillary acidic protein; GRX1, glutaredoxin 1; GSH, reduced glutathione; GSSG, oxidized glutathione; HIV, human immunodeficiency virus; IGF-I, insulin-like growth factor-I; JNK, c-Jun N-terminal kinase; MAPKKK, mitogen-activated protein kinase kinase
}

kinase; $\mathrm{MCB}$, monochlorobimane; MEM, minimum essential medium; MTT, 3-(4,5-dimethyl-2-thiazolyl)-2,5-diphenyl-2H-tetrazolium bromide; ORF, open reading frame; PI3K, phosphatidylinositol 3-kinase; PLSD, post least significant distance; PMSF, phenylmethylsulfonyl fluoride; TCA, trichloroacetic acid; TRX1, thioredoxin 1; TRXR, thioredoxin reductase

\section{Introduction}

Alzheimer's disease $(A D)$ is characterized by several neuropathological changes, including accumulation of intracellular neurofibrillary tangles and extracellular plaques, as well as vast synaptic and neuronal loss. The main constituent of $A D$ plaques is the $39-43$ amino-acid long, amyloid $\beta(A \beta)$ peptide. $\mathrm{A} \beta$ deposition has been proposed as the major pathogenic event that drives AD pathology. ${ }^{1}$ The precise mechanisms leading to $\mathrm{A} \beta$ neurotoxicity are not fully understood, but several evidences, from both in vitro and in vivo studies, suggest that oxidative stress plays a key role (for review, see Huang et al. ${ }^{2}$ ). A $\beta$ has been shown to induce apoptosis in several paradigms, ${ }^{3}$ and signs of activation of apoptosis have been shown in both transgenic models of $A D$ and in postmortem $A D$ brain samples, ${ }^{4,5}$ supporting the idea that the progressive cell loss seen in AD involves apoptosis. Glutaredoxins (GRX) and thioredoxins (TRX) are endogenous antioxidant systems and key players in the balance of cellular redox homeostasis. Two glutaredoxin genes (GRX) have been found in mammals, GRX1 and GRX2. ${ }^{6}$ GRX1 encodes GRX1, a protein that resides mainly in the cytoplasm although it can translocate into the nucleus upon certain stimuli. GRX2 encodes two isoforms, a mitochondrial and a nuclear GRX2. When oxidized, the GRX isoforms are regenerated by reduced glutathione $(\mathrm{GSH})$. The resulting oxidized glutathione (GSSG) is in turn reduced by glutathione reductase at the expense of NADPH. These molecules form the glutaredoxin system in which GRX1 plays a prevalent role (Figure 1a). ${ }^{6}$ At least two TRX isoforms have been characterized in mammals, cytosolic (TRX1) and mitochondrial (TRX2), of which TRX1 is the major redox protein. TRX is reduced by TRX reductase (TRXR) via NADPH. The TRX system is completed by a TRX peroxidase that is reduced by TRX and additionally scavenges reactive oxidative species (Figure $1 b$ ). ${ }^{6}$

In addition to their role in oxidative stress, GRX1 and TRX1 have been shown to regulate apoptosis through the apoptosis signal-regulating kinase-1 (ASK1) cascade. ASK1 is a mitogen-activated protein kinase kinase kinase (MAPKKK) that is bound to the reduced state of either GRX1 or TRX1. When GRX1 or TRX1 are oxidized, ASK1 is liberated and can initiate the MAPK cascade leading to activation of c-Jun $\mathrm{N}$-terminal kinase (JNK) or p38, ${ }^{7,8}$ as well as to the translocation of death-associated protein (Daxx) from the nucleus to the cytosol. ${ }^{9}$ The exogenous administration or overexpression of GRX1 or TRX1 is protective against apoptosis, as shown in several studies. ${ }^{10,11}$ Whether this is achieved 
a

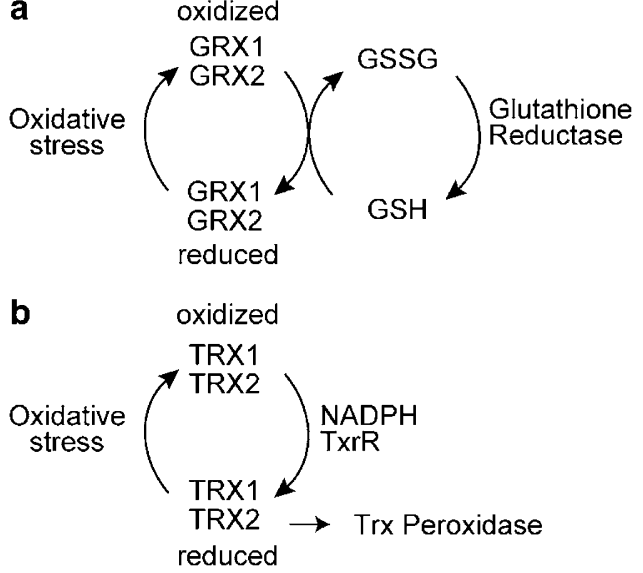

Figure 1 Glutaredoxin (a) and thioredoxin (b) systems

through an inhibition of the ASK1 cascade or through other ASK1-independent mechanisms is not yet clear.

Recently, it was suggested that ASK1 activation is a key mechanism in $A \beta$ neurotoxicity, ${ }^{12}$ but if this activation is GRX1/TRX1 dependent remains to be explored. The role of GRX1 and TRX1 in AD is largely unknown, but a few reports over recent years, albeit conflicting, suggest a possible involvement of these proteins in protection from $A D$ oxidative stress. In an mRNA expression profiling study of $A D$ hippocampal CA1 neurons, GRX1 was found to be downregulated in tangle-bearing neurons compared to normal neurons in AD brains. ${ }^{13}$ Protein levels of TRX1 have also been found to be decreased in AD brain in areas associated with $A D$ pathology. ${ }^{11}$ In contrast, Asahina et al. ${ }^{14}$ showed that, in $A D$ brain, TRX1 staining was increased in astrocytes in the white matter, and suggested that this reflects the need for increased antioxidant protection.

The present study aims to provide insight into the role of GRX1 and TRX1 in $A \beta$ toxicity and AD. We first investigated the expression of GRX1 and TRX1 in AD brain. Then, using human neuroblastoma SH-SY5Y cells, we analyzed the effects of $A \beta$ on the redox states of GRX1 and TRX1, and on other antioxidant systems, specifically catalase and glutathione. Finally, we investigated the possible involvement of the ASK1 cascade in $A \beta$-mediated apoptosis and the possible protective effects of GRX1 and TRX1 overexpression.

\section{Results}

\section{GRX1 and TRX1 expressions in AD brain}

Figure 2 shows immunohistochemical studies of GRX1 (Figure 2a) and TRX1 (Figure 2b) expressions in frontal cortex and hippocampal CA1 regions of AD brains and agematched controls. Both brain regions are widely affected in $A D$. The number of neurons and its staining intensity were estimated using a stereological semiquantitative approach. The results are summarized in Table 1. We found that GRX1 expression was increased in neurons of AD brains (Table 1, Figure 2a). In contrast, TRX1 expression was reduced a
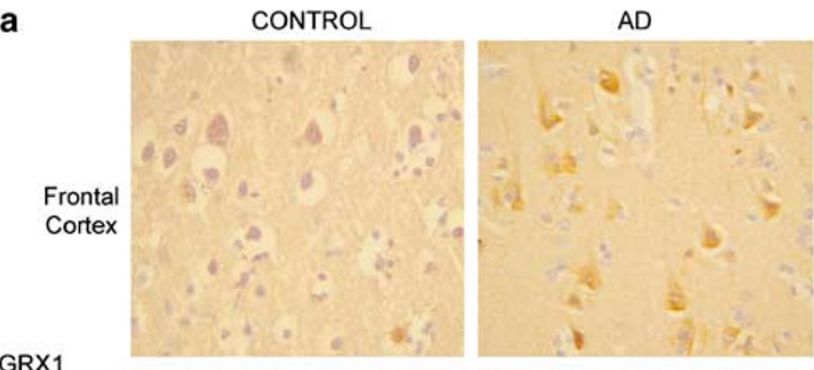

GRX1
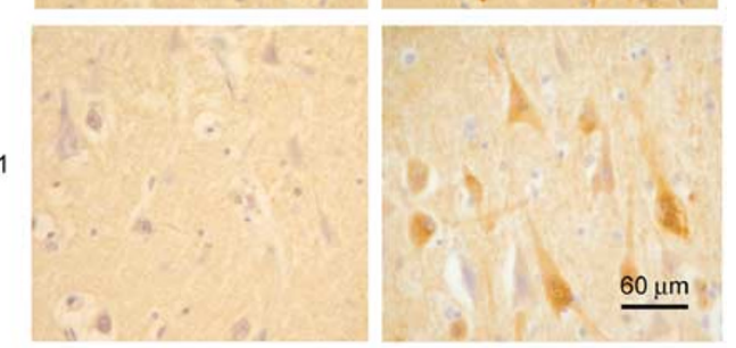

b
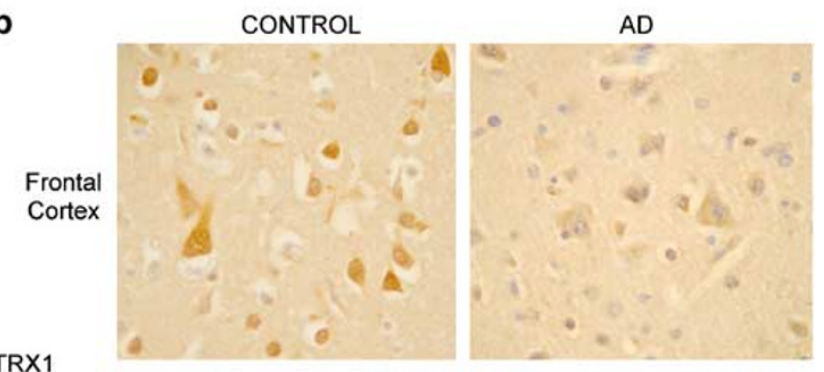

TRX
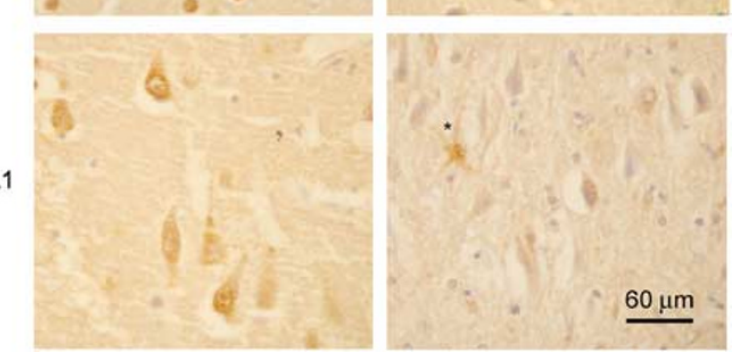

Figure 2 Expression of GRX1 and TRX1 in AD brains. (a) Immunostaining of GRX1 and (b) TRX1 in frontal cortex and hippocampal CA1 regions from one AD brain (female, 80 years old) and one control brain (female, 83 years old). GRX1 expression was increased, while TRX1 expression decreased in neurons of $A D$ brains. In $A D$ brains, an occasional increase in immunoreactivity was found in astrocyte-like profiles for TRX1 (asterisk) in all regions analyzed. Similar expression patterns were seen in the other brains studied

(Table 1, Figure 2b). Similar results were found in slices from hippocampal dentate gyrus (data not shown).

In controls, GRX1 was localized mostly in the cytosolic compartment (Figures 2a and 3a) and was particularly visible in layer II, III and V pyramidal neurons. Generally, for control brains, cortical pyramidal neurons showed more immunoreactivity than hippocampal pyramidal cells. In AD brains, hippocampal neurons showed in general more immunoreactivity than cortical neurons. In AD brains, healthy neurons as determined according to Oppenheimer's criteria, including the central position of the nucleus and the presence of a single large conspicuous nucleolus, ${ }^{15}$ displayed intensive GRX1 cytoplasmic positivity even in dendritic compartments (Figures 2a, 3b and d). This was in contrast to neurons with morphological features indicating neurodegeneration 
(changes in the body shape, deformation and shifting of the nucleus to the periphery or disappearance of nucleolus), especially in hippocampal areas where a specific form of pyramidal cell degeneration (granulovacuolar degeneration) was visible (Figure $3 e$ ).

TRX1 immunoreactivity was also mainly present in the cytosol, with no differences in intensity between brain regions. TRX1 was greatly decreased in $A D$ brains compared with

Table 1 Quantification of GRX1- and TRX1-immunopositive neurons

\begin{tabular}{|c|c|c|}
\hline & Controls & AD \\
\hline \multicolumn{3}{|l|}{ Anti-GRX1 } \\
\hline \multicolumn{3}{|l|}{ Frontal cortex } \\
\hline Total cells $/ \mathrm{mm}^{2}$ & $98000 \pm 10700$ & $64000 \pm 8700$ \\
\hline Heavily stained cells (\%) & $\overline{4}$ & $93 . \overline{7}$ \\
\hline Low or nonstained cells (\%) & 96 & 6.2 \\
\hline \multicolumn{3}{|l|}{ Hippocampus (CA1) } \\
\hline Total cells $/ \mathrm{mm}^{2}$ & $115 \pm 15$ & $110 \pm 17$ \\
\hline Heavily stained cells (\%) & 3.4 & $8 \overline{5}$ \\
\hline Low or nonstained cells (\%) & 96.6 & 15 \\
\hline \multicolumn{3}{|l|}{ Anti-TRX1 } \\
\hline \multicolumn{3}{|l|}{ Frontal cortex } \\
\hline Total cells $/ \mathrm{mm}^{2}$ & $98000 \pm 10700$ & $64000 \pm 8700$ \\
\hline Heavily stained cells (\%) & $8 \overline{6}$ & 11.7 \\
\hline Low or nonstained cells (\%) & 14 & 88.3 \\
\hline \multicolumn{3}{|l|}{ Hippocampus (CA1) } \\
\hline Total cells $/ \mathrm{mm}^{2}$ & $115 \pm 15$ & $110 \pm 17$ \\
\hline Heavily stained cells (\%) & 84.3 & $5 \overline{4}$ \\
\hline Low or nonstained cells (\%) & 15.7 & 46 \\
\hline
\end{tabular}

Quantification of GRX1- and TRX1-positive neurons. Total number of cells is presented \pm SD. Number of stained cells is given as percentage of total number of cells
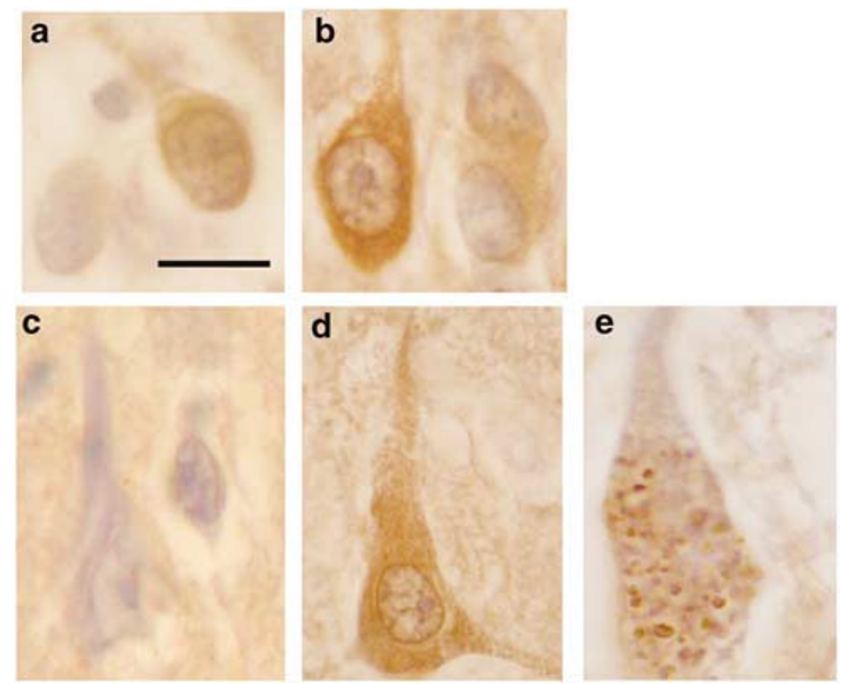

Figure 3 GRX1 immunoreactivity is increased in healthy neurons in $A D$. Staining of individual neurons with the anti-GRX1 antibody in hippocampus, dentate gyrus from control (a) and $A D$ (b) brains and in $C A 1$ region from contro (c) and $A D(\mathbf{d}, \mathbf{e})$ brains. The neurons with high immunoreactivity of GRX1 in $A D$ brains (b, d) showed a normal morphology (shape, central nucleus, single nucleolus). In contrast, signs of neurodegeneration such as displaced nucleus and granulovacuolar degeneration were found in $A D$ brain neurons with low GRX1 expression (e). Bar $=10 \mu \mathrm{m}$ controls (Figure 2b). Additionally, we found occasional positively stained astrocyte-like profiles in AD brains (asterisk in Figure 2b). Hematoxylin was used as a background staining (blue). As seen in Figure 2, no differences were seen in hematoxylin staining in all the sections.

GRX1 is only expressed in neurons, while TRX1 is expressed in both neurons and glial cells. In addition, both neuronal loss and increased gliosis are characteristic features of $A D$ brains. ${ }^{16}$ Taking these facts in account, we further analyzed the expression of GRX1 and TRX1 in AD and control brains by immunoblotting. Indeed, we saw a decrease in neuronal synaptophysin and an increase in glial fibrillary acidic protein (GFAP) in AD brains (Figure 4) as indicators of neuronal loss and enhanced gliosis, respectively. As shown in Figure 4, no major differences were seen in GRX1 and TRX1 immunoreactivity in homogenates from AD and control brains. These results together with those seen in immunohistochemistry (Table 1 and Figure 2) indicate that the reduced number of neurons present in AD brains express more GRX1. In addition, an increased number of glial cells in AD brains masks the differences seen in neuronal TRX1 when brain homogenates are analyzed.

\section{A $\beta$ oxidizes GRX1 and TRX1 in a rapid, transient manner}

GRX1 and TRX1 are redox active proteins that can have several different redox states, varying from fully reduced to fully oxidized, depending on the surrounding cellular environment. To analyze the effects of $A \beta$ on GRX1 and TRX1 redox states, we exposed human SH-SY5Y cells for 1,5 and $24 \mathrm{~h}$ to full-length $\mathrm{A} \beta(1-42)(10 \mu \mathrm{M})$, the shorter $\mathrm{A} \beta(25-35)(10 \mu \mathrm{M})$ and the reverse and non-toxic form $\mathrm{A} \beta(35-25)(10 \mu \mathrm{M})$. Figure 5 shows the separation between the different redox states after incubation of the samples with AMS (4-acetamido-

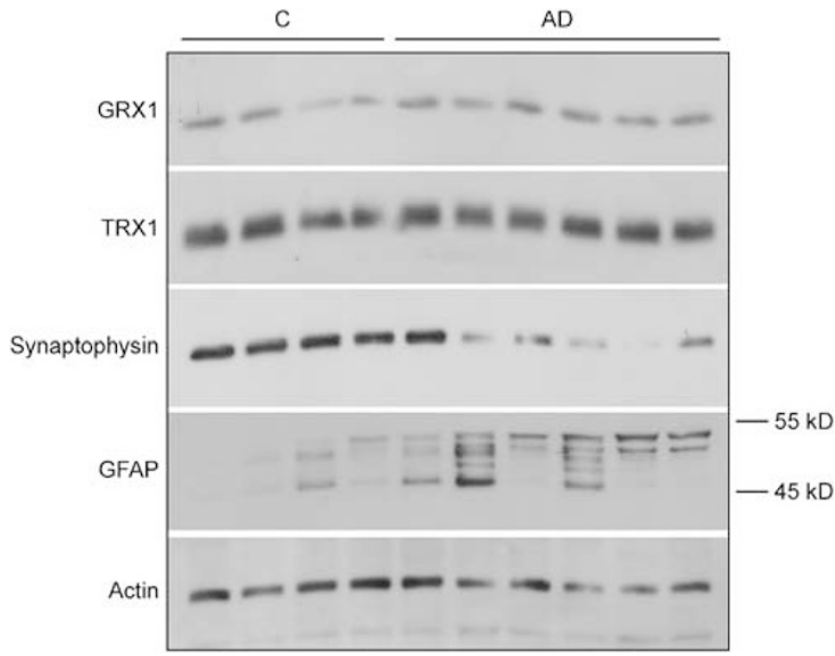

Figure 4 Immunoblotting of brain GRX1 and TRX1. Immunoblots of temporal cortex homogenates from control and AD cases using antibodies against GRX1, TRX1, the neuronal marker synaptophysin, the glial marker GFAP and actin. No differences were found in GRX1 and TRX1 expression between AD and control brain homogenates. As expected, synaptophysin levels were reduced and GFAP increased in $\mathrm{AD}$ reflecting neuronal loss and gliosis 


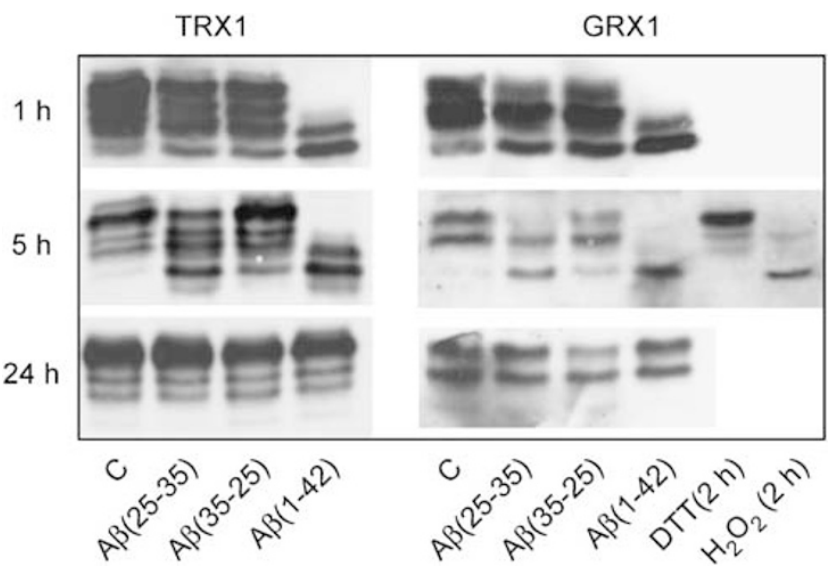

Figure 5 Effects of $A \beta$ on the redox states of GRX1 and TRX1. GRX1 and TRX1 immunoblots of lysates from cells treated with $10 \mu \mathrm{M}$ of $\mathrm{A} \beta(1-42), \mathrm{A} \beta(25-$ 35 ) or the reverse $A \beta(35-25)$ for 1,5 and $24 \mathrm{~h}$, as well as untreated cells (C). AMS was added to the samples to separate the different redox forms. To confirm the specificity of each band, reducing (DTT; $10 \mathrm{mM}, 2 \mathrm{~h})$ and oxidizing $\left(\mathrm{H}_{2} \mathrm{O}_{2}\right.$; $1 \mathrm{mM}, 2 \mathrm{~h}$ ) treatments were used. Three independent experiments gave similar results

4'-maleimidyl-stilbene-2,2'-disulfonate) and subsequent gel electrophoresis. As determined using reducing (dithiothreitol (DTT), $10 \mathrm{mM})$ or oxidizing $\left(\mathrm{H}_{2} \mathrm{O}_{2}, 1 \mathrm{mM}\right)$ conditions, the upper band is the fully reduced and the lower the fully oxidized redox state (Figure 5).

As shown in Figure $5, \mathrm{~A} \beta(1-42)(10 \mu \mathrm{M})$ induced an early and transient oxidation of both GRX1 and TRX1, seen at 1 and $5 \mathrm{~h}$, but not at $24 \mathrm{~h}$. A $\beta(25-35)(10 \mu \mathrm{M})$ effects were very mild and also transient, being seen only at $5 \mathrm{~h}$ treatment. In contrast, the reverse peptide $\mathrm{A} \beta(35-25)(10 \mu \mathrm{M})$ did not induce any significant effect.

\section{Effects of $A \beta(1-42)$ on catalase and glutathione antioxidant systems}

We next analyzed the effects of $A \beta(1-42)$ on two other major cellular antioxidant systems, namely catalase and glutathione by measuring catalase activity and levels of GSH. Catalase is an antioxidant enzyme involved in the degradation and detoxification of $\mathrm{H}_{2} \mathrm{O}_{2}$ and glutathione is the main redox buffer in the cell. SH-SY5Y cells were treated for 1,5 and $24 \mathrm{~h}$ with $\mathrm{A} \beta(1-42)(10 \mu \mathrm{M}) . \mathrm{A} \beta(1-42)$ significantly increased catalase activity after 5 and $24 \mathrm{~h}$ (Figure $6 \mathrm{a}$ ). $\mathrm{A} \beta(1-42)$ decreased $\mathrm{GSH}$ levels at $24 \mathrm{~h}$ with no effect at earlier time points (Figure $6 \mathrm{~b}$ ).

\section{$A \beta(1-42)$ induces apoptosis and Daxx translocation in SH-SY5Y cells}

GRX1 and TRX1 have been shown to be regulators of the apoptosis cascade mediated by ASK1. When reduced, GRX1 and TRX1 are bound to ASK1, thereby inhibiting its activity. In contrast, when they are oxidized ASK1 is free to initiate apoptosis. $\mathrm{A} \beta(1-42)$ has been shown to induce apoptosis in several in vitro models. Since we showed that $A \beta(1-42)$ caused an early oxidation of both GRX1 and TRX1, we next analyzed the effects of $\mathrm{A} \beta(1-42)$ on apoptosis and the possible involvement of the ASK1 apoptotic cascade in the
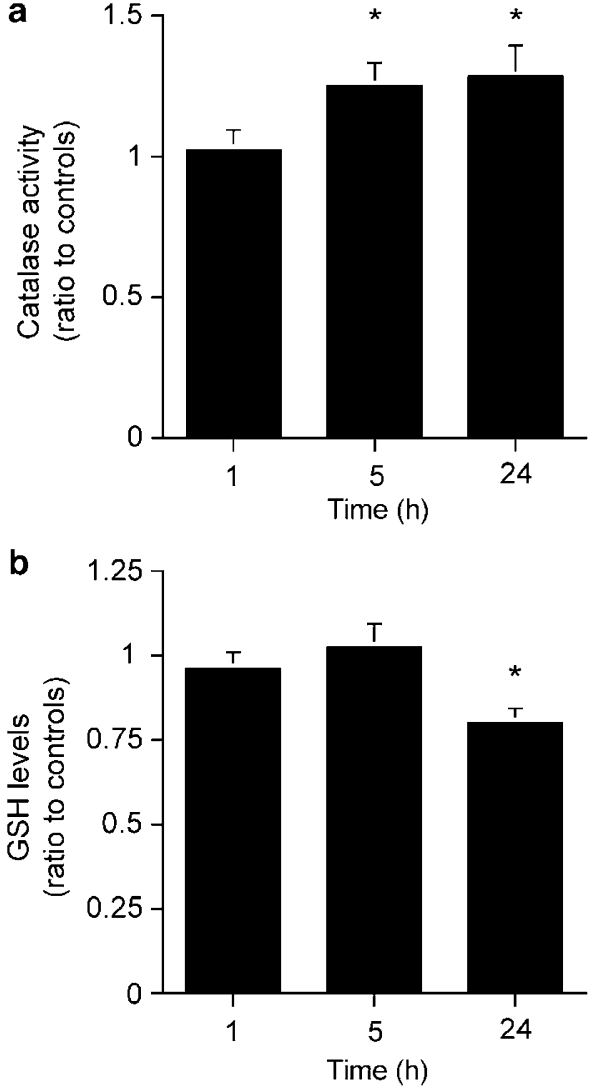

Figure 6 Effects of $A \beta(1-42)$ on (a) catalase activity and on (b) GSH levels. Cells were treated for 1,5 or $24 \mathrm{~h}$ with $10 \mu \mathrm{M} \mathrm{A} \beta(1-42)$. Untreated cells were used as controls (C). Data are mean \pm S.E.M. of six experiments expressed as ratio of values for untreated control cells. Statistical analysis of the results was carried out using ANOVA followed by Fisher's PLSD post hoc test. ${ }^{*} P<0.05$

A $\beta(1-42)$-mediated cytotoxicity. We first studied effects on cell viability using the 3-(4,5-dimethyl-2-thiazolyl)-2,5-diphenyl$2 \mathrm{H}$-tetrazolium bromide (MTT)-reduction assay. A $\beta(1-42)$ $(10 \mu \mathrm{M})$ inhibited MTT reduction by approximately $30 \%$ at $2 \mathrm{~h}$ and by $40 \%$ at 5 and $24 \mathrm{~h}$. This effect was significant with time $(P<0,001$; ANOVA), (see Figure 7 a for comparisons at each time point). $\mathrm{A} \beta(1-42)(10 \mu \mathrm{M})$ gave increased levels of apoptosis in a time-dependent manner $(P<0.001$; ANOVA), with approximately 300 and $600 \%$ increases in monoand oligo-nucleosome levels after 5 and $24 \mathrm{~h}$ treatment, respectively, as compared to nontreated cells (Figure $7 \mathrm{~b}$ ).

To investigate the involvement of the ASK1 cascade in the $\mathrm{A} \beta(1-42)$-induced apoptosis, we analyzed the $\mathrm{A} \beta(1-42)$ effects on Daxx translocation from the nuclei to the cytosol.

Daxx is a downstream protein in the ASK1 cascade. Activation of ASK1 induces Daxx phosphorylation and its translocation to the cytosolic compartment by a JNKmediated mechanism. ${ }^{9}$ Figure $8 a$ and $c$ shows Daxx immunoblots of cytosolic and nuclear fractions of cells treated with $\mathrm{A} \beta(1-42)(10 \mu \mathrm{M})$ for 2 and $24 \mathrm{~h}$. A treatment with $\mathrm{H}_{2} \mathrm{O}_{2}$ (1 $\mathrm{mM}, 20 \mathrm{~min}$ ) was also used as a positive control for the experiment. Quantitative analysis of the blots with data expressed as ratios of nuclear Daxx to total amount of Daxx showed that the $\mathrm{A} \beta(1-42)$-induced translocation was statistically significant already after $2 \mathrm{~h}$ treatment (Figure $8 \mathrm{~b}$ ). 

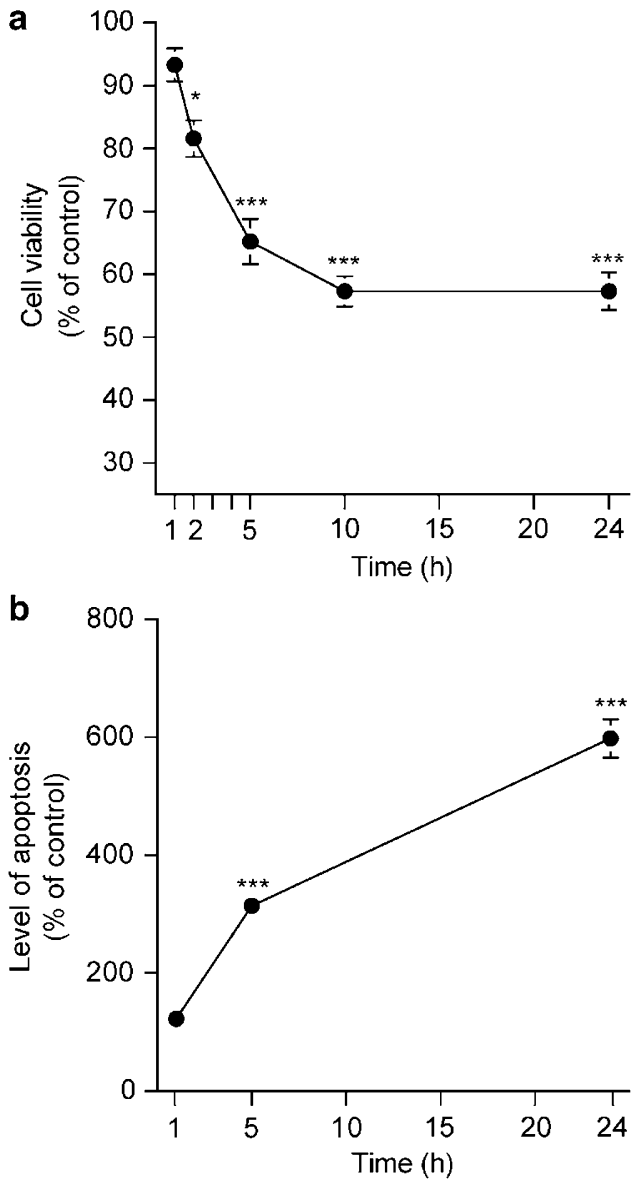

Figure $7 \quad \mathrm{~A} \beta(1-42)$ reduces cell viability and induces apoptosis in SH-SY5Y cells. (a) Effects of $10 \mu \mathrm{M} \mathrm{A} \beta(1-42)$ on MTT reduction. Cells were treated for 1,2 5,10 or $24 \mathrm{~h}$. Four experiments were performed in triplicate. (b) Effects of $10 \mu \mathrm{M}$ $\mathrm{A} \beta(1-42)$ on apoptosis. Cells were treated for 1,5 or $24 \mathrm{~h}$. Three experiments were performed in triplicate. Data (mean \pm S.E.M.) are expressed as percentage of values in untreated cells ( ${ }^{\star} P<0.05 ;{ }^{* \star} P<0.001$; ANOVA followed by Fisher's PLSD post hoc test)

To ensure the loading of gels and purity of the fractions, the same membranes were stripped and reblotted for the nuclearspecific protein Lamin A (nuclear fractions and cytosolic fractions) and actin (cytosolic fractions) (Figure 8a and c).

$\mathrm{A} \beta(1-42)$ effects on Daxx relocalization were further analyzed with immunocytochemistry. As shown in Figure 8d, $10 \mu \mathrm{M} \mathrm{A} \beta(1-42)$ induces translocation of Daxx from the nucleus to the cytosol at both 5 and $24 \mathrm{~h}$. A treatment with $\mathrm{H}_{2} \mathrm{O}_{2}(1 \mathrm{mM}, 20 \mathrm{~min})$ was used as a positive control for the experiment.

\section{IGF-I protects against $\mathrm{A} \beta$ toxicity in a PI3K- independent manner}

IGF-I has been shown to protect against $A \beta$ toxicity in several cellular paradigms. ${ }^{17,18}$ This protection has been shown to involve both activation of extracellular signal-regulated kinase (ERK) and phosphatidylinositol 3-kinase (PI3K) signaling pathways. ${ }^{18}$ IGF-I has also been shown to inhibit ASK1 activity and therefore apoptosis, by a mechanism that is independent of its effects on the PI3K antiapoptotic

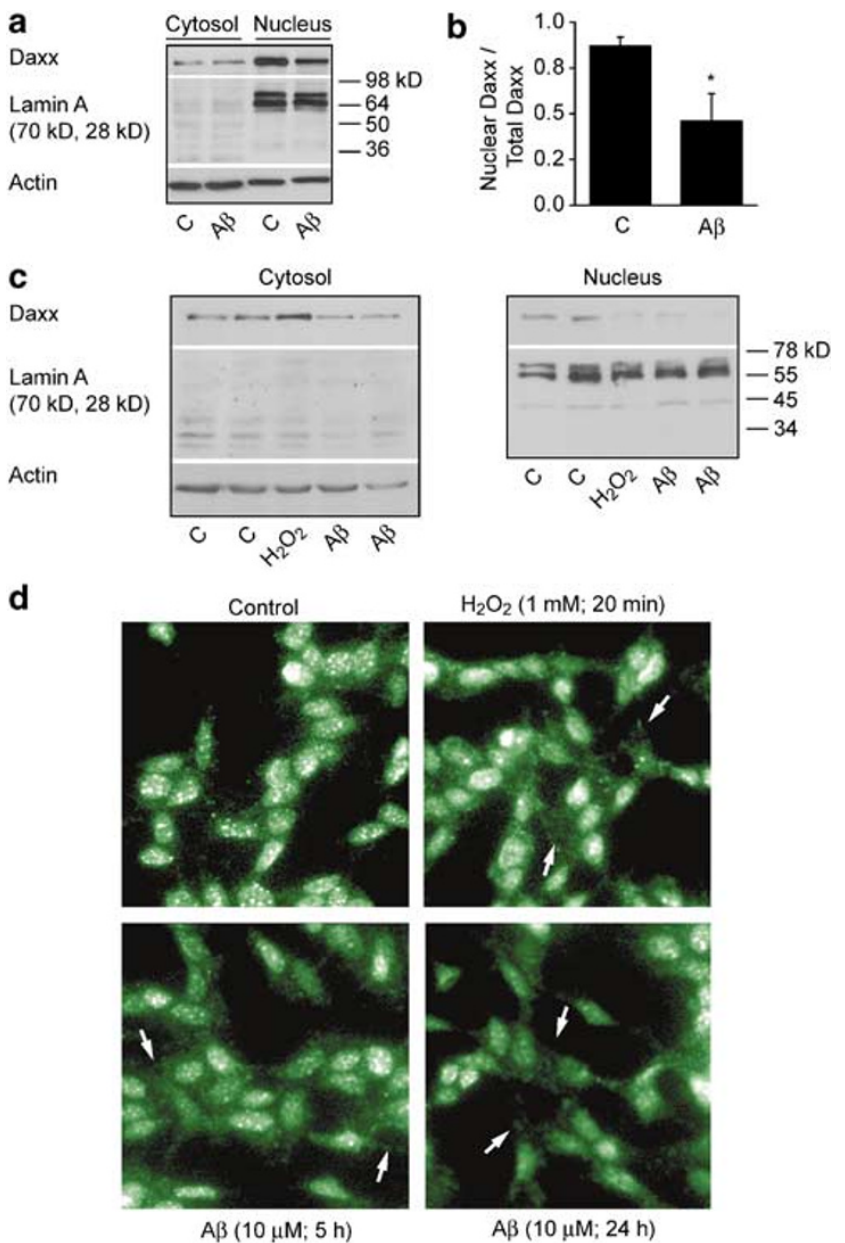

Figure $8 \quad A \beta(1-42)$ induces Daxx translocation in SH-SY5Y cells. Immunoblots of cytosolic and nuclear fractions of cells treated with $\mathrm{A} \beta(1-42)(10 \mu \mathrm{M})$ for (a) $2 \mathrm{~h}$ and (c) $24 \mathrm{~h}$ using anti-Daxx, anti-Lamin and anti-actin antibodies. Untreated cells were used as controls (C). A treatment with $\mathrm{H}_{2} \mathrm{O}_{2}(1 \mathrm{mM})$ for 20 min was used as a positive control. (b) Quantification of the $A \beta(1-42)$ effects on Daxx translocation at $2 \mathrm{~h}$. Histogram shows the mean \pm S.E.M of values from four independent experiments with data expressed as ratio of nuclear Daxx to total Daxx. Significant differences were determined using Student's $t$-test. ${ }^{*} P<0.05$. (d) Micrographs of SH-SY5Y cells that were untreated (Control), treated with $1 \mathrm{mM} \mathrm{H}_{2} \mathrm{O}_{2}$ for $20 \mathrm{~min}$ or with $10 \mu \mathrm{M} \mathrm{A} \beta(1-42)$ for 5 and $24 \mathrm{~h}$ and then stained for Daxx. In untreated cells, Daxx immunofluorescence was concentrated mainly in the nuclei. Both $\mathrm{A} \beta(1-42)$ and $\mathrm{H}_{2} \mathrm{O}_{2}$ treatments induced translocation of Daxx and immunofluorescence was seen in the cytosolic projections of SH-SY5Y cells. Arrows indicate some examples

cascade. ${ }^{17}$ We next analyzed the protective effects of IGF-I against $\mathrm{A} \beta(1-42)$ toxicity when ERK or PI3K antiapoptotic pathways were inhibited. For this, we coincubated cells with IGF-I $(20 \mathrm{nM})$ and $\mathrm{A} \beta(1-42)(10 \mu \mathrm{M})$ with and without the specific inhibitors LY294002 (50 $\mu \mathrm{M}$; for PI3K) and U0126 $(5 \mu \mathrm{M}$; for MEK, an upstream kinase of ERK) and then analyzed cell viability using the MTT assay.

The inhibitors were used in a $30 \mathrm{~min}$ pretreatment and during the coincubations with $A \beta(1-42)$ and IGF-I. The efficiency of the inhibitors was previously checked by immunoblotting extracts of treated cells with anti-phosphoAkt (a downstream serine/threonine kinase that is phosphorylated by PI3K) and anti-phospho-ERK antibodies. These 
antibodies recognize active forms of Akt and ERK. LY294002 $(50 \mu \mathrm{M})$ and U0126 $(5 \mu \mathrm{M})$ strongly inhibited Akt and ERK phosphorylation, respectively, at both 2 and $5 \mathrm{~h}$ (Figure 9a), without changing total expression levels of these proteins as demonstrated by immunoblotting with anti-Akt and anti-ERK antibodies (data not shown).

To analyze the putative effects of IGF-I against $A \beta(1-42)$ toxicity, we selected a $5 \mathrm{~h}$ treatment, since at this time point we previously showed that $\mathrm{A} \beta(1-42)$ induces apoptosis. As shown in Figure 9b, IGF-I (20 nM) fully protected SH-SY5Y cells against $\mathrm{A} \beta(1-42)$ toxicity $(P<0.001)$. When PI3K was blocked by LY294002 $(50 \mu \mathrm{M})$, IGF-I was still protective $(P<0.001)$. However, PI3K inhibition slightly decreased the IGF-I protection $(P<0.05$ against both controls and IGF-I treated cells) (Figure 9b). When ERK was blocked by U0126

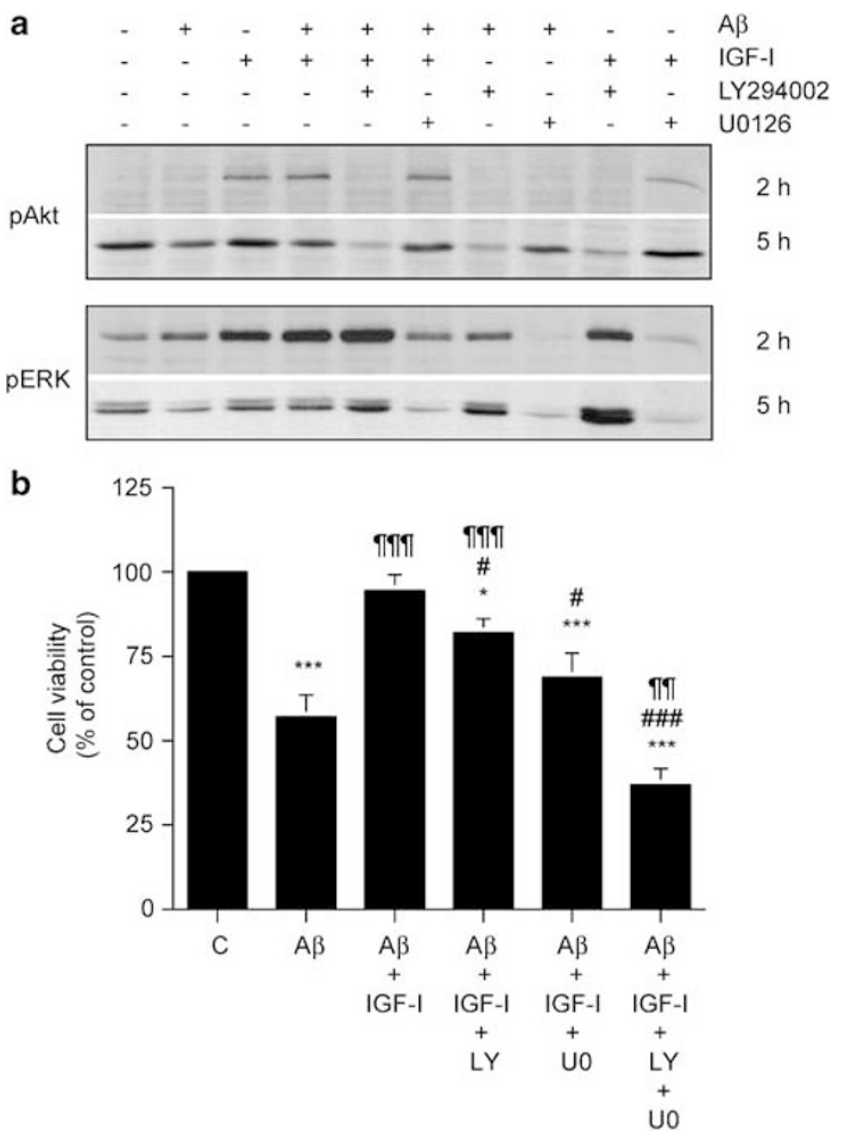

Figure 9 IGF-I protects against $\mathrm{A} \beta$ toxicity in a PI3K-independent manner. (a) Immunoblotting for phospho-Akt or phospho-ERK in SH-SY5Y cells after the following treatments: untreated, $A \beta(1-42)(10 \mu \mathrm{M})$, IGF-I $(20 \mathrm{nM})$, coincubation of IGF-I (20 nM) with $\mathrm{A} \beta(1-42)(10 \mu \mathrm{M})$ without and with the specific inhibitors LY294002 (50 $\mu \mathrm{M}$; for PI3K) and U0126 ( $5 \mu \mathrm{M}$; for MEK/ERK). The inhibitors were used in a 30 min pretreatment and during the incubations with the different conditions for 2 and $5 \mathrm{~h}$. (b) Effects of IGF-I $(20 \mathrm{nM})$ on $\mathrm{A} \beta(1-42)(10 \mu \mathrm{M})$ induced decrease of cell viability. $C=$ untreated cells; $A \beta=A \beta(1-42)(10 \mu \mathrm{M}$, $5 \mathrm{~h}) ; \mathrm{A} \beta+\mathrm{IGF}-\mathrm{I}=$ coincubation of $\mathrm{A} \beta(1-42)(10 \mu \mathrm{M})$ and IGF-I $(20 \mathrm{nM})$ for $5 \mathrm{~h}$; $\mathrm{LY}=\mathrm{LY} 294002(50 \mu \mathrm{M}) ; \mathrm{U} 0=\mathrm{U} 0126(5 \mu \mathrm{M})$. Inhibitors $\mathrm{LY}$ and $\mathrm{UO}$ were used in a 30 min pretreatment and during the coincubations with $A \beta(1-42)$ and IGF-I. Data are expressed as percentage of values for untreated cells and represent the mean + S.E.M of three experiments performed in triplicate $\left({ }^{*} P<0.05\right.$; ${ }^{* * *} P<0.001$ against untreated cells. " $P<0.01$; ${ }^{*} P<0.001$ versus $A \beta$ treated cells. ${ }^{\#} P<0.05$; ${ }^{\# \#} P<0.001$ versus $A \beta+$ IGF-I-treated cells; ANOVA followed by Fisher's PLSD post hoc test)
$(5 \mu \mathrm{M})$, IGF-I did not protect against $\mathrm{A} \beta(1-42)$ toxicity (Figure 9b). IGF-I/A $\beta(1-42)$ cotreatment with simultaneous inhibition of both PI3K and ERK was more toxic than $\mathrm{A} \beta(1-42)$ alone $(P>0.01)$.

\section{Overexpression of GRX1 or TRX1 protects cells from $A \beta$ toxicity}

The effects of overexpression of GRX1 or TRX1 on A $\beta(1-42)$ toxicity in SH-SY5Y cells were evaluated by studying cell viability with the MTT assay. SH-SY5Y cells were transiently transfected with either GRX1, TRX1 or the empty vector as negative control. As shown in Figure 10a, GRX1 and TRX1 expression levels were significantly increased after transfection.

Then, cells were incubated with $10 \mu \mathrm{M} \mathrm{A} \beta(1-42)$ for $24 \mathrm{~h}$ and cell viability was determined. Treatment with $\mathrm{A} \beta(1-42)$ $(10 \mu \mathrm{M})$ decreased MTT reduction by approximately $40 \%$ in all the experiments with nontransfected and vector-transfected cells $(P<0.001)$ (Figures $10 \mathrm{~b}-\mathrm{d})$. Overexpression of TRX1 completely protected cells from $\mathrm{A} \beta(1-42)$ toxicity (Figure $10 \mathrm{~b})$. Overexpression of $\mathrm{GRX} 1$ also protected cells against $\mathrm{A} \beta(1-42)$ toxicity $(P<0.001)$ but not to the same extent as seen with TRX1. A $\beta(1-42)$ treatment in GRX1-transfected cells still decreased MTT reduction to approximately $80 \%$, a level that was significantly different to both nontransfected and vector-transfected cells $(P<0.05)$ (Figure 10c). Transfection of cells with empty vector had no effect on $\mathrm{A} \beta(1-42)$ toxicity (Figure 10d).

\section{Discussion}

Oxidative stress is believed to have an early role in $A D$ pathology and several reports have suggested that endogenous antioxidant systems could be affected in the disease. ${ }^{19,20}$ The GRX1 and TRX1 endogenous antioxidant systems are key players in maintaining the cellular redox status. ${ }^{6}$ In addition to their role as antioxidants, both GRX1 and TRX1 have been shown to regulate apoptosis. Reduced GRX1 and TRX1 are able to bind to ASK1 and inhibit the proapoptotic MAPK cascade that leads to the activation of JNK, p38 and to the cytosolic translocation of Daxx. ${ }^{7,8}$ It is well known that $\mathrm{A} \beta$ triggers the production of ROS, inducing neuronal cell death (reviewed in Small et al. ${ }^{3}$ ). Very recently Kadowaki et al. ${ }^{12}$ demonstrated that activation of ASK1 was a key event in A $\beta$ toxicity. Despite their importance as regulators of oxidative stress and apoptosis, the role of GRX1 and TRX1 in AD is largely unknown. To provide insight of GRX1 and TRX1 in the context of $A D$, we addressed the roles of GRX1 and TRX1 in the mechanisms of $A \beta$ neurotoxicity and how $G R X 1$ and TRX1 levels are affected in $A D$.

We found that GRX1 levels were increased in some neurons in both frontal cortex and hippocampal CA1 regions of $A D$ brains. In contrast, we found a reduction of neuronal TRX1 levels in the same regions. This is the first study showing expression levels of GRX1 in AD brain. Two previous reports studied TRX1 in AD. Lovell et al. ${ }^{11}$ reported a general decrease of TRX1 from several regions in AD brains. This is in apparent agreement with our study, although it was made in 
a
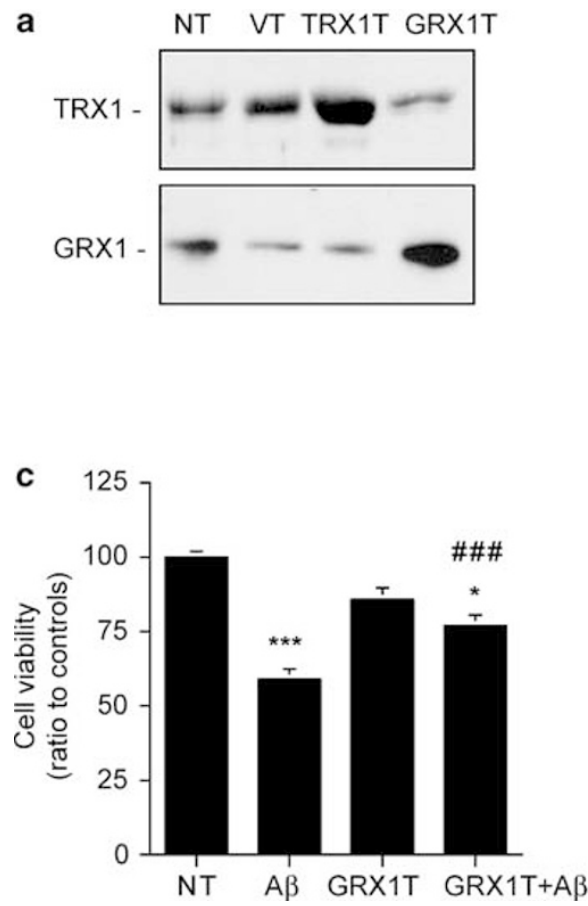

b
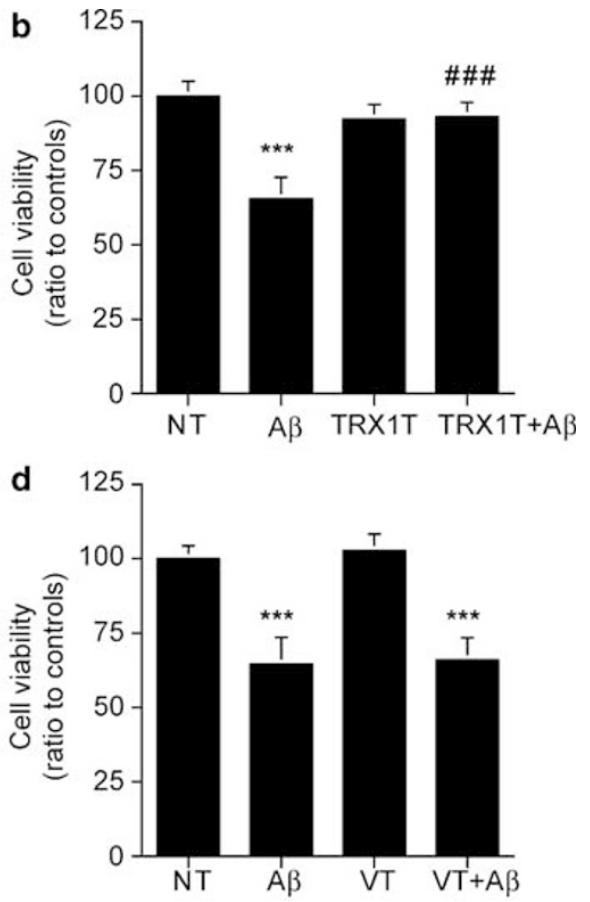

Figure 10 Overexpression of GRX1 or TRX1 protects cells from A $\beta$ toxicity. (a) Immunoblotting of GRX1 or TRX1 expression in nontransfected (NT), pIRES vector (VT), pIRES/GRX1 (GRX1T) and pIRES/TRX1 (TRX1T) transiently transfected human SH-SY5Y neuroblastoma cells. Effects of $\mathrm{A} \beta(1-42)(10 \mu \mathrm{M}, 24 \mathrm{~h})$ on cell viability in (b) GRX1-transfected, (c) TRX1-transfected and (d) vector-transfected cells. Data represent the mean values from seven to nine wells $\pm S$.E.M. and are expressed as percentage of values for untreated cells in the respective experiments. $\left({ }^{\star} P<0.05{ }^{* \star *} P<0.001\right.$ versus untreated cells; ${ }^{\# \#} P<0.001$ versus A $\beta(1-42)$-treated cells; ANOVA followed by Fisher's PLSD post hoc test)

brain homogenates containing both neuronal and glial TRX1. In an earlier report, Asahina et al. ${ }^{14}$ saw an increase of TRX1 levels in astrocytes in AD brains as compared to healthy controls. In contrast with our study and with the observations of others, ${ }^{21}$ no staining in neurons was reported in this article. However, as discussed in the results section, an increased TRX1 immunoreactivity in AD glial cells would further confirm the hypothesis that differences in neuronal TRX1 are masked when brain homogenates are analyzed.

The expressions of both GRX1 and TRX1 have been reported to be induced by various types of oxidative stress (for a review, see Grant ${ }^{22}$ ). However, a decrease in TRX1 levels has previously been shown to occur in some diseases involving oxidative conditions, such as in neurons from spontaneously hypertensive rats. ${ }^{23}$ The fact that $\mathrm{TRX} 1$ also modulates a number of transcription factors ${ }^{24}$ and stresssignaling kinases, like ASK $1^{25}$ involved in apoptosis, suggests that a decrease of TRX1 may contribute to the neurodegenerative mechanisms of $A D$. On the other hand, the simultaneous increase of GRX1 in neurons of $A D$ brains may also be of importance. The fact that those neurons overexpressing GRX1 showed an apparent normal morphology suggests that they could possibly have a better protection against the neurodegenerative events occurring in AD. In accordance with this idea, a previous report has shown that in tangle-bearing hippocampal CA1 neurons, GRX1 mRNA levels were reduced six times as compared to normal neurons in $A D$ brains.

The upregulation of GRX1 seen in $A D$ brain could be a compensatory effect to counteract the reduction of TRX1. An inverse relation between Grx1 and Trx1 expression has been demonstrated in Escherichia coli, where Grx1 levels are increased in bacteria lacking Trx1 and vice versa. ${ }^{26}$ In addition, a functional link between Grx and Trx expressions has also been described in yeast, where a lack of Trx causes a decrease in GSH levels, which are compensated for by an increased Grx expression. ${ }^{27}$ A reduction of $\mathrm{GSH}$ levels has been previously demonstrated in $A D$ brain, ${ }^{28}$ suggesting the possibility of a similar mechanism.

We treated human SH-SY5Y neuroblastoma cells with different $A \beta$ species and examined the redox status of GRX1 and TRX1. $A \beta$ is a key molecule in AD pathology and has been shown to be neurotoxic by different mechanisms including the induction of oxidative stress (for a review, see Small et al. ${ }^{3}$ ). We found that $A \beta(1-42)$ caused a strong and early oxidation of both GRX1 and TRX1 that was transient with time. The intensity and early nature of these effects were in contrast with those seen for other antioxidant systems. We showed that catalase activity was increased at 5 and $24 \mathrm{~h}$ and levels of GSH were decreased after $24 \mathrm{~h}$ in response to $\mathrm{A} \beta(1-42)$ treatment. Our results suggest that GRX1 and TRX1 are in the first line of response against the oxidative stress caused by $\mathrm{A} \beta(1-42)$, at least in SH-SY5Y neuroblastoma cells. As previously discussed, the reduction in GSH levels is in accordance with earlier reports from studies with $A D$ brain ${ }^{28}$ and also with other in vitro studies. ${ }^{29}$ The decrease in GSH levels could further suggest that glutathione participates in the recuperation of reduced GRX1 seen at $24 \mathrm{~h}$ (see Figure 1). On the other hand, the recuperation of reduced TRX1, seen at $24 \mathrm{~h}$, could indicate an additional upregulation of the reducing 
mechanisms of TRX1, that is, TRXR. In agreement with this idea TRXR levels have been shown to be increased in AD. ${ }^{11}$

Several reports have shown that $A \beta$ induces apoptosis in a number of different models (for a review, see Small et al. ${ }^{3}$ ). On the other hand, both GRX1 and TRX1 have been shown to be negative regulators of ASK1, a stress-activated and apoptotic-inducing kinase. This negative regulation of apoptosis is dependent on the redox state of GRX1 and TRX1. ASK1 is bound to the reduced form of GRX1 and TRX1, but when GRX1 and TRX1 are oxidized ASK1 is free and can initiate apoptosis. ${ }^{7}$ In view of this, we hypothesized that the strong and quick oxidation of GRX 1 and TRX1 by $A \beta$, albeit transient, could participate in the mechanism by which $A \beta$ is proapoptotic, by liberating ASK1. Indeed, we first showed that $A \beta(1-42)$ decreased cell viability and induced apoptosis in our paradigm. We then demonstrated the involvement of the ASK1 cascade by showing that $\mathrm{A} \beta$ induced cytosolic translocation of Daxx at 2, 5 and $24 \mathrm{~h}$ treatment. Daxx is a downstream protein in the ASK1 pathway located in the nucleus under normal conditions. However, under oxidative stress, ASK1 activates JNK, which phosphorylates Daxx and uncovers a nuclear export signal leading to translocation of Daxx to the cytoplasmic compartment. ${ }^{9}$ It has also been observed that Daxx is involved in the activation of ASK $1 .{ }^{30}$ In concordance with our finding that $\mathrm{A} \beta$ induced cytosolic translocation of Daxx, Kadowaki et al. ${ }^{12}$ showed that ASK1 is activated by $\mathrm{A} \beta$ in PC12 cells, and that ASK1 is in fact necessary for $A \beta$ toxicity. In primary neuronal cultures derived from $\mathrm{E} 14.5 \mathrm{ASK}^{-1-}$ mice, JNK activation by $\mathrm{A} \beta$ was excluded and cell viability was almost four-fold compared to $\mathrm{ASK}^{+/+}$ cells. Also, others have shown that ASK1 is required for oxidative stress-induced activation of JNK, a downstream kinase of $A S K 1,{ }^{31}$ and that $A S K 1$ is critical for $A \beta$ toxicity in SH-SY5Y cells. ${ }^{18}$ This evidence together with our results strongly suggests that activation of ASK1 is a key mechanism for $\mathrm{A} \beta$ neurotoxicity. Furthermore, since $\mathrm{GRX} 1$ and TRX1 when oxidized no longer bind to ASK1 leading to its activation, it is also suggested that the strong and early oxidation of GRX1 and TRX1 by A $\beta$ could participate in this mechanism.

To further investigate this hypothesis, we next analyzed possible strategies of protection against $A \beta$ toxicity based on inhibiting ASK1 and on overexpressing GRX1 or TRX1. Previous studies have shown that IGF-I protects cells from $\mathrm{A} \beta$ toxicity. This protection has been shown to involve both activation of ERK and PI3K signaling pathways by IGF-I. ${ }^{18}$ In a recent work, Galvan et al. ${ }^{17}$ demonstrated that IGF-I treatment inhibits the ASK1 activation seen in serum-starved L929 cells independently of the PI3K pathway. Others have also shown that ASK1 can be inhibited by Akt, a serine/ threonine kinase that is activated by $\mathrm{PI} 3 \mathrm{~K}^{32}$ In view of this, we analyzed the ability of IGF-I to protect against $A \beta(1-42)$ in our model when PI3K and/or ERK pathways were blocked with the specific inhibitors LY294002 and U0126, respectively. We showed that IGF-I completely protected against $\mathrm{A} \beta(1-42)$ induced cell death. In accordance with Galvan et al., ${ }^{17}$ inhibition of PI3K did not have a strong effect on the IGF-I protection against $\mathrm{A} \beta$ toxicity. IGF-I was not protective when the MEK/ERK or both PI3K/Akt and MEK/ERK pathways were inhibited. These results provide supplementary evidence that ASK1 activation is a likely important component of the mechanism of $\mathrm{A} \beta$ toxicity and that this toxicity may be prevented by pharmacological inhibition of ASK1.

Our results from brain tissue indicate that increased levels of GRX1 could be protective. Finally, we explored the possibility that increased levels of GRX1 or TRX1 protect SHSY5Y cells from $A \beta$ toxicity. A number of reports have shown that raised levels of GRX or TRX by exogenous recombinant administration or by overexpression protect cells against several insults. ${ }^{10,33,34}$ Here, we showed that increasing levels of GRX1 or TRX1 by transient transfection protect against $\mathrm{A} \beta(1-42)$ toxicity in SH-SY5Y cells. Taking these results together with those seen in AD brains, an increase of GRX1 in healthy neurons and the general decrease of TRX1, it is suggested that increased brain levels of GRX1 and TRX1 could be beneficial for counteracting $A \beta$ toxicity and possibly also the progression of $A D$ pathogenesis.

In summary, we demonstrate that in AD brains, GRX1 levels are increased in neurons without signs of degeneration, while neuronal TRX1 levels are generally decreased. We also demonstrate that $\mathrm{A} \beta(1-42)$ caused an early, strong and transient oxidation of both GRX1 and TRX1, and induced apoptosis by activation of the ASK1 cascade in SH-SY5Y cells. We show that pharmacological inhibition of ASK1 by IGF-I as well as overexpression of GRX1 or TRX1 protect cells against $A \beta(1-42)$ toxicity. In view of this, we propose a model (Figure 11) by which $A \beta$ toxicity could occur primarily by causing oxidative stress. The GRX1 and TRX1 endogenous antioxidant systems are in the first line of defense to try to maintain the cellular redox homeostasis. However, GRX1 and TRX1 oxidations cause the liberation and activation of ASK1 and subsequent initiation of apoptosis.

Our results strongly suggest that deregulation of GRX1 and TRX1 antioxidant systems could be important in the pathogenesis of $A D$. Moreover, strategies leading to inhibition of

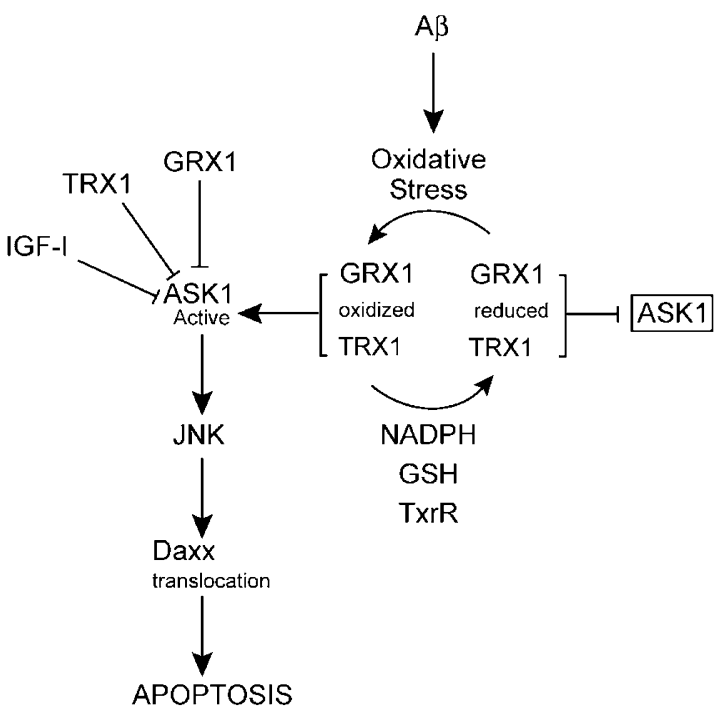

Figure 11 Schematic representation of the involvement of GRX1 and TRX1 on $A \beta(1-42)$ toxicity. Oxidative stress caused by $A \beta$ induces a strong early oxidation of GRX1 and TRX1. As a consequence, the inhibitory binding of GRX1 and TRX1 to ASK1 is disrupted and ASK1 is liberated and initiates an apoptosis cascade. Treatment with IGF-I or overexpression of GRX1 or TRX1 inhibits ASK1 and protects cells against the $A \beta$ toxicity 
ASK1 or to an increase of GRX1 or TRX1 in neurons may have therapeutic applications for the treatment of this disease.

\section{Materials and Methods}

\section{Materials}

$\mathrm{A} \beta(25-35)$ and $A \beta(35-25)$ were purchased from Sigma-Aldrich (Stockholm, Sweden). A $\beta(1-42)$ was from US Peptide (Rancho Cucamonga, CA, USA) and dissolved in serum-free minimum essential medium (MEM). Before use, the $A \beta$ was incubated at $37^{\circ} \mathrm{C}$ with sporadic shaking for $48 \mathrm{~h} .{ }^{35}$ Others have shown that similar preparations of $A \beta(1-42)$ contain $\mathrm{A} \beta$ fibrils along with protofibrils and stable oligomers. ${ }^{36}$

AMS was from Molecular Probes (Leiden, The Netherlands). Catalase, Purpald, trichloroacetic acid (TCA), okadaic acid, phenylmethylsulfonyl fluoride (PMSF), leupeptin, aprotinin, IGF-I and thiazolyl blue tetrazolium bromide (MTT-salt) were from Sigma-Aldrich (Stockholm, Sweden). Potassium periodate was purchased from Scharlau Chemie (Barcelona, Spain). LY294002 was from Calbiochem (La Jolla, CA, USA). U0126 was from Cell Signaling Technology (Beverly, MA, USA). All other chemicals were standard laboratory reagents.

\section{Brain samples and tissue preparation}

Post-mortem brain material was obtained from the Huddinge Brain Bank (Karolinska University Hospital, Sweden) with approval by the Human Ethics Committee of Karolinska University Hospital. Four definite AD brains (two males, 79 and 89 years old; two females, 76 and 80 years old) and three age-matched control (two males, 66 and 83 years old; one 85 -year-old female) were used for immunohistochemistry. All brains had a post-mortem delay between 24 and $48 \mathrm{~h}$. For immunoblotting, samples from temporal cortex from six AD brains (two males and four females, $84 \pm 9$ years old) and four controls (four males, $66 \pm 7$ years old) were used. The brains had a post-mortem delay between 8 and $34 \mathrm{~h}$. The $A D$ cases met the clinical diagnosis of probable $A D$ (Diagnostic and Statistical Manual of Mental Disorders-IV, DSM-IV criteria) as well as definite $A D$ after Consortium to establish a Registry for Alzheimer's disease (CERAD) neuropathological criteria. ${ }^{37}$

Brain samples intended for immunocytochemistry were fixed in buffered $4 \%$ formaldehyde and embedded in paraffin. For immunoblotting, brain samples were sonicated $4 \times 15 \mathrm{~s}$ in a buffer consisting of $40 \mathrm{mM}$ Tris- $\mathrm{HCl}$ (pH 6.8) and $2 \%$ SDS, with freshly added protease inhibitor cocktail (Sigma-Aldrich, Saint Louis, MO, USA) at a dilution of 1:500 and phosphatase inhibitors (20 mM $\beta$-glycerophosphate, $2 \mathrm{nM}$ okadaic acid, $50 \mathrm{mM}$ sodium flouride, $1 \mathrm{mM}$ sodium orthovanadate).

\section{Immunohistochemical analysis}

Sections ( $7 \mu \mathrm{m}$ thick) were mounted onto Superfrost plus-glass (Menzel Braunschweig, Germany), baked at $37^{\circ} \mathrm{C}$ overnight, dewaxed and hydrated. Then, sections were blocked for nonspecific sites with Dakoprotein block (X0909) (Dako, Cytomation, Denmark) for $30 \mathrm{~min}$ prior to incubations over night at $4^{\circ} \mathrm{C}$ with primary antibodies (anti-GRX1 or antiTRX1). Then, sections were incubated for $30 \mathrm{~min}$ with secondary antibody diluted in TBS, followed by incubation in ABC-Elite HRP (Vector laboratories Burlingame, UK) for $1 \mathrm{~h}$. Reactions were visualized by developing the sections in Dab (Sigma-Aldrich, Sweden). The sections were thoroughly washed in TBS between different steps. Finally, the sections were dehydrated and mounted in DPX (BDH, Poole, UK). The protocol for antibodies was repeated to assure the reproducibility of results. All sections were treated simultaneously under the same conditions. For control staining, the primary antibody was omitted. For morphological recognition of the neurons, hematoxylin staining was used as a background.

\section{Stereological semiquantification of immunohistochemistry}

Stereological semiquantification was performed as previously described. ${ }^{38}$ The regions used were dorsal frontal cortex pyramidal layer III, CA1 region of hippocampus and granular cell layer of dentate. A computer-generated counting frame was superimposed on the screen of a CAST-GRID 1.2 software program (Olympus, Denmark). Three slides per brain were examined. According to the intensity of the neuronal staining, the cells were divided in two groups: heavily stained cells and low or nonstained cells.

\section{Cell culture}

Human neuroblastoma SH-SY5Y cells were cultured in MEM with Earle's salts and L-alanine and L-glutamine, supplemented with $10 \%$ fetal bovine serum (FBS), $100 \mathrm{U} / \mathrm{ml}$ penicillin, $100 \mu \mathrm{g} / \mathrm{ml}$ streptomycin at $37^{\circ} \mathrm{C}$ in a humidified atmosphere of $5 \%(\mathrm{v} / \mathrm{v}) \mathrm{CO}_{2} /$ air. All cell culture supplies were purchased from Gibco Invitrogen Corporation (European division, Täby, Sweden). Before treatments, cells were washed with serum-free MEM. All treatments were used under serum-free conditions. Untreated cells were used as controls.

\section{Redox state assessment}

Cells were treated with $\mathrm{A} \beta(25-35)(10 \mu \mathrm{M}), \mathrm{A} \beta(35-25)(10 \mu \mathrm{M})$ or $\mathrm{A} \beta(1-42)(10 \mu \mathrm{M})$ in MEM medium ( $\mathrm{pH} 7.4)$ under serum-free conditions, for 1,5 or $24 \mathrm{~h}$. Untreated cells were used as controls. After treatment, cells were washed with ice-cold phosphate-buffered saline (PBS). To quench further disulfide exchange and preserve the post-treatment cellular oxidation state, the cells were rapidly treated with $20 \%(\mathrm{w} / \mathrm{v})$ trichloroacetic acid (TCA). ${ }^{39}$ Cells were harvested and collected by centrifugation $(2000 \times g$ for $10 \mathrm{~min})$ at $+4^{\circ} \mathrm{C}$. TCA-treated pellets were washed twice with $70 \%$ acetone and resuspended in sample buffer $(62.5 \mathrm{mM}$ Tris- $\mathrm{HCl}$ $\mathrm{pH} 7.5,2 \%$ SDS, $10 \%$ glycerol, $0.001 \%$ bromophenol blue) with freshly added protease inhibitors (50 $\mu \mathrm{g} / \mathrm{ml} \mathrm{PMSF,} 20 \mu \mathrm{g} / \mathrm{ml}$ leupeptin, $20 \mu \mathrm{g} / \mathrm{ml}$ aprotinin). In order to dissolve the TCA precipitates completely, the samples were sonicated. Samples were stored frozen at $-80^{\circ} \mathrm{C}$ prior to immunoblotting. Samples were boiled for $3 \mathrm{~min}$ at $95^{\circ} \mathrm{C}$ prior to incubation with the thiol-specific probe AMS overnight at room temperature. AMS covalently modifies the reduced form of the proteins, which markedly retards electrophoretic migration of proteins in SDS-PAGE and gives an unequivocal separation of oxidized and reduced forms of the proteins. ${ }^{39}$ Protein concentrations were determined using the bicinchoninic acid (BCA) protein assay kit (Pierce, Rockford, IL, USA). Equivalent amounts of protein were separated by SDS-PAGE using 15 or $18 \%$ acrylamide gels.

\section{Immunoblotting}

Immunoblotting was performed as previously described. ${ }^{35}$ Table 2 shows the different primary antibodies used. Some of the immunoblots were stripped using stripping buffer $(62.5 \mathrm{mM}$ Tris- $\mathrm{HCl}, \mathrm{pH} 6.7,2 \%$ SDS, $100 \mathrm{mM}$ mercaptoethanol) at $+50^{\circ} \mathrm{C}$ for $30 \mathrm{~min}$, and then reblotted. 
Table 2 Summary of antibodies and working conditions used in the experiments

\begin{tabular}{|c|c|c|c|c|}
\hline Antibody & Species & Source & $\begin{array}{c}\text { Dilution/ } \\
\text { concentration }\end{array}$ & $\begin{array}{l}\text { Incubation time/ } \\
\text { temperature }\end{array}$ \\
\hline \multicolumn{5}{|l|}{ Primary antibodies } \\
\hline Anti-actin & Rabbit, polyclonal & Sigma-Aldrich, St. Louis, MO, USA & $1: 1000$ & Overnight, $+4^{\circ}$ \\
\hline $\begin{array}{l}\text { Anti-phospho Akt } \\
\text { (Ser } 473)\end{array}$ & Rabbit, polyclonal & Cell Signaling Technology, Beverly, MA, USA & $1: 1000$ & Overnight, $+4^{\circ}$ \\
\hline Anti-Daxx & Mouse, monoclonal & MBL Int. Corp., Woburn, MA, USA & $1: 100^{\mathrm{c}}, 1: 1000^{\mathrm{a}}$ & $1 \mathrm{~h}$, room temp. \\
\hline Anti-phospho ERK & Rabbit, polyclonal & Cell Signaling Technology, Beverly, MA, USA & $1: 1000$ & Overnight, $+4^{\circ}$ \\
\hline Anti-GFAP & Mouse, monoclonal & BD Biosciences Erembodegem, Belgium & $1: 1000$ & Overnight, room temp. \\
\hline Anti-GRX1 & Goat, polyclonal & IMCO Corp., Stockholm, Sweden & $1: 1000$ & Overnight, room temp. \\
\hline Anti-Lamin A & Rabbit, polyclonal & Cell Signaling Technology, Beverly, MA, USA & $1: 1000$ & Overnight, $+4^{\circ}$ \\
\hline Anti-Synaptophysin & Mouse, monoclonal & DAKO Cytomation, Glostrup, Denmark & $1: 1000$ & $2 \mathrm{~h}$, room temp. \\
\hline Anti-TRX1 & Goat, polyclonal & IMCO Corp., Stockholm, Sweden & $1: 1000$ & Overnight, room temp. \\
\hline \multicolumn{5}{|l|}{ Secondary antibodies } \\
\hline Anti-goat lgGa (HRP) & Horse & Vector Laboratories, Burlingame, CA, USA & $1: 1000$ & $1 \mathrm{~h}$, room temp. \\
\hline $\begin{array}{l}\text { Anti-goat lgG } \\
\text { (Biotin) }\end{array}$ & Rabbit & DAKO Cytomation, Glostrup, Denmark & $5 \mu \mathrm{g} / \mathrm{ml}$ & $1 \mathrm{~h}$, room temp. \\
\hline $\begin{array}{l}\text { Anti-mouse lgG } \\
\text { (HRP) }\end{array}$ & Sheep & Amersham Biosciences, Little Chalfont, England & $1: 2000$ & $1 \mathrm{~h}$, room temp. \\
\hline \multirow{3}{*}{$\begin{array}{l}\text { Anti-mouse } \operatorname{lgG}^{c} \\
\text { (Alexa Fluor 488) } \\
\text { Anti-rabbit lgG } \\
\text { (HRP) }\end{array}$} & Goat & Molecular Probes, Leiden, The Netherlands & $1: 1000$ & $1 \mathrm{~h}$, room temp. \\
\hline & & & & \\
\hline & Donkey & $\mathrm{Ar}$ & 0 & $1 \mathrm{r}$ \\
\hline
\end{tabular}

aImmunoblotting. ${ }^{\mathrm{I} I m m u n o h i s t o c h e m i s t r y . ~}{ }^{\mathrm{C}}$ Immunofluorescence

For the experiments including IGF-I, cells were either left untreated or treated with $50 \mu \mathrm{M}$ LY294002 and/or $5 \mu \mathrm{M}$ U0126 for 30 min prior and during cotreatment with $10 \mu \mathrm{M} \mathrm{A} \beta(1-42)$ and $20 \mathrm{nM}$ IGF-I for $5 \mathrm{~h}$. Cells were then washed with PBS, harvested, and collected by centrifugation at $+4^{\circ} \mathrm{C}(2000 \times \mathrm{g}, 10 \mathrm{~min})$. Cells were lysed with lysis buffer $(20 \mathrm{mM}$ Tris$\mathrm{HCl} \mathrm{pH} \mathrm{7.4,} 137 \mathrm{mM} \mathrm{NaCl}, 2$ mM EDTA, 2\% NP-40, 2\% Triton X-100) with freshly added protease inhibitor cocktail (Sigma-Aldrich, Saint Louis, MO, USA) at a dilution of 1:500 and phosphatase inhibitors $(20 \mathrm{mM}$ $\beta$-glycerophosphate, $2 \mathrm{nM}$ okadaic acid, $50 \mathrm{mM}$ sodium flouride, $1 \mathrm{mM}$ sodium orthovanadate). Lysates were stored frozen at $-80^{\circ} \mathrm{C}$.

\section{Determination of catalase activity}

Catalase activity was determined as described elsewhere. ${ }^{40}$ Cells were grown in $6 \mathrm{~cm}^{2}$ polystyrene plates. After treatment, the cells were washed with ice-cold PBS, harvested and collected by centrifugation at $+4^{\circ} \mathrm{C}(2000 \times \mathrm{g}$ for $10 \mathrm{~min})$. Pellets were suspended in $50 \mathrm{mM}$ $\mathrm{K}_{3} \mathrm{PO}_{4} \mathrm{pH} 7.0,1 \mathrm{mM}$ EDTA buffer and sonicated. The cell lysates were centrifuged again at $+4^{\circ} \mathrm{C}(10000 \times \mathrm{g}$ for $15 \mathrm{~min})$ and supernatants were saved and stored frozen at $-80^{\circ} \mathrm{C}$ prior to analyses. The assay utilizes the peroxidatic activity of catalase to transform methanol and $\mathrm{H}_{2} \mathrm{O}_{2}$ into formaldehyde. The chromagen Purpald was used to visualize the formation of formaldehyde, by measuring the absorbance at $550 \mathrm{~nm}$ in a plate reader spectrophotometer (Molecular Devices Spectra MAX 250). The analysis was performed in 96-well plates using formaldehyde as standard $(0-75 \mu \mathrm{M})$. Care was taken during the whole sample preparation not to overheat cell lysates, since this can inactivate catalase.

\section{Measurement of reduced glutathione levels}

A GSH detection kit (Chemicon, Temecula, CA, USA) was used according to the manufacturer's protocol to detect GSH levels. This kit uses the dye monochlorobimane (MCB) that has a high affinity for GSH. When unbound, MCB is almost nonfluorescent, whereas GSH-bound dye fluoresces blue. Fluorescence was measured by a FLUOstar
Galaxy multiwell plate reader (BMG Labtechnologies $\mathrm{GmbH}$, Offenburg, Germany), the excitation and emission wavelengths being 380 and $460 \mathrm{~nm}$, respectively.

\section{Cell viability and apoptosis measurements}

Cell viability was assessed by a modified version of the MTT assay that depends on the reduction of the tetrazolium salt MTT to formazan by living cells. ${ }^{35}$ Cells were cultured in 24-well plates and treated for the indicated time points with $10 \mu \mathrm{M} \mathrm{A} \beta(1-42)$. For the experiments including IGF-I, medium was changed to serum-free MEM and the cells were either left untreated or treated with $50 \mu \mathrm{M} \mathrm{LY} 294002$ and/or $5 \mu \mathrm{M}$ U0126 for 30 min prior and during cotreatment with $10 \mu \mathrm{M} \mathrm{A} \beta(1-42)$ and $20 \mathrm{nM} \mathrm{IGF-I} \mathrm{for} 5 \mathrm{~h}$.

After treatment, a MTT solution $(0.3 \mathrm{mg} / \mathrm{ml})$ made in serum-free MEM without phenol red was added to the cells. After $1 \mathrm{~h}$ incubation at $37^{\circ} \mathrm{C}$, the MTT solution was aspirated and isopropanol was added to the cells. Aliquots were transferred to a 96-well plate and absorbances measured at $540 \mathrm{~nm}$ in a plate reader spectrophotometer (Molecular Devices Spectra MAX 250). Results were expressed as percentages of the respective value obtained for untreated cells at each time point.

Detection of apoptotic mono- and oligo-nucleosomes was performed using the Cell Death Detection ELISA ${ }^{\text {PLUS }}$ kit (Roche Diagnostics Scandinavia AB, Bromma, Sweden) according to the manufacturer's instructions. The assay is based on a quantitative sandwich ELISA using mouse monoclonal antibodies directed against DNA and histones, respectively. This renders the in vitro determination of apoptosischaracteristic mono- and oligo-nucleosomes possible. The assay was performed in 96-well plates, measured spectrophotometrically at $405 \mathrm{~nm}$ (Molecular Devices Spectra MAX 250).

\section{Immunocytochemistry}

Cells grown on chamber slides were fixed in methanol for $30 \mathrm{~min}$ on ice. Nonspecific binding of antibodies was blocked by addition of $10 \%$ BSA in TBS-t for $30 \mathrm{~min}$. Cells were incubated with primary antibody (Table 2) 
diluted in TBS-t with 3\% BSA. Cells were rinsed in TBS-t $(3 \times 10 \mathrm{~min})$ before incubation with secondary antibody in TBS-t with $3 \%$ BSA for $1 \mathrm{~h}$ in the dark. Finally, cells were rinsed in TBS-t $(3 \times 10 \mathrm{~min})$ and mounted in fluorescence mounting medium (DAKO Cytomation, Glostrup, Denmark). Nikon Eclipse E800 microscope and Nikon FDX35 camera were used when analyzing the result of the immunocytochemistry.

\section{Subcellular fractionation}

Nuclear and cytosolic fractions of cells were isolated using the nuclear and cytoplasmic extraction reagents kit NE-PER (Pierce, Rockford, IL, USA), according to the manufacturer's protocol. Protease inhibitor cocktail (Sigma-Aldrich, Saint Louis, MO, USA) was added freshly at a dilution of $1: 500$. Purity of fractions was assessed by immunoblotting with antiLamin-A antibody, a nuclear membrane protein used as specific nuclear marker. Densitometric analysis of immunoreactive bands on immunoblots was performed by multiplying the optical density and the area of the selected band, obtained through NIH Image 1.63 software.

\section{DNA constructs and transfections}

The mutagenic forward primers $5^{\prime}$-CGAATTCGCCACCATGGATTACAAG GATGACGACGATAAGGCTCAAGAGTTTGTGAAC-3' for GRX1 and 5'CGAATTCGCCACCATGGATTACAAGGATGACGACGATAAGATGGTG AAGCAGATCGAG-3' for TRX1, and the reverse primers $5^{\prime}$-CGGATCCTT ACTGCAGAGCTCCAATC- $3^{\prime}$ for GRX 1 and $5^{\prime}$-CGGATCCTTAGACTAAT TCATTAAT-3' for TRX1 were used to amplify the respective open reading frames (ORF) by PCR from human testis Marathon-ready ${ }^{\mathrm{TM}} \mathrm{CDNA}$ (Clontech, Heidelberg, Germany). The forward primers introduced an EcoRI site followed by a Kozac sequence preceding the Flag epitope sequence and the corresponding GRX1 or TRX1 sequences. The reverse primers introduced a BamHI site after the GRX1 or TRX1 stop codons. The amplified DNA was cloned into the EcoRI-BamHI sites of the pIRESneo expression vector (Clontech, Heidelberg, Germany) and the resulting plasmids pIRES/GRX1 and pIRES/TRX1 were transformed into $E$. coli TOP-10 $\mathrm{F}^{\prime}$ strain. The final constructs were purified using the midi-prep kit (QIAGEN Sciences, Maryland, USA) and confirmed by DNA sequencing.

Transient transfections were performed in 12-well plates using Lipofectamine $^{\mathrm{TM}} 2000$ (Gibco Invitrogen Corporation; European division, Täby, Sweden) according to the manufacturer's instructions. SH-SY5Y cells were cultured until 90\% confluence in 12-well plates and transfected with $0.8 \mu \mathrm{g}$ of DNA. Cells were incubated for $24 \mathrm{~h}$ before changing media for serum-free MEM with or without $10 \mu \mathrm{M} \mathrm{A} \beta(1-42)$ and cells were treated for $24 \mathrm{~h}$ prior to measuring cell viability.

\section{Statistical analyses}

Analyses of differences were carried out by Student's $t$-test or by ANOVA followed by Fisher's PLSD post hoc test. A value of $P<0.05$ was considered statistically significant.

\section{Acknowledgements}

We thank Inga Volkman and Anna Sandebring for their technical assistance. This research was supported by grants from the following Swedish foundations: Hjärnfonden (Swedish Brain Foundation), Gun och Bertil Stohnes Stiftelse, Karolinska Institutets Foundation for geriatric research, Loo and Hans Ostermans Foundation, Åke Wiberg Foundation,
Svenska Lundbeck-stiftelsen, Demensförbundet, Alzheimer Foundation; Sweden, Lars Hiertas minnesstiftelse, Gamla Tjänarinnor foundation, Insamlingsstiftelsen för Alzheimer och demenforskning (SADF) and Swedish Brain Power project. AM-V was supported by Swedish Medical Research Council (Projects 03P-14096, 03X-14041, and 13X-10370). AJ was supported by a postdoctoral fellowship EX2003-0390 from the Spanish Ministerio de Educacion, Cultura y Deporte.

\section{References}

1. Hardy JA and Higgins GA (1992) Alzheimer's disease: the amyloid cascade hypothesis. Science 256: 184-185

2. Huang X, Moir RD, Tanzi RE, Bush Al and Rogers JT (2004) Redox-active metals, oxidative stress, and Alzheimer's disease pathology. Ann. N. Y. Acad. Sci. 1012: 153-163

3. Small DH, Mok SS and Bornstein JC (2001) Alzheimer's disease and Abeta toxicity: from top to bottom. Nat. Rev. Neurosci. 2: 595-598

4. LaFerla FM, Tinkle BT, Bieberich CJ, Haudenschild CC and Jay G (1995) The Alzheimer's A beta peptide induces neurodegeneration and apoptotic cell death in transgenic mice. Nat. Genet. 9: 21-30

5. Stadelmann C, Deckwerth TL, Srinivasan A, Bancher C, Bruck W, Jellinger K and Lassmann $H$ (1999) Activation of caspase-3 in single neurons and autophagic granules of granulovacuolar degeneration in Alzheimer's disease. Evidence for apoptotic cell death. Am. J. Pathol. 155: 1459-1466

6. Holmgren A (2000) Antioxidant function of thioredoxin and glutaredoxin systems. Antioxid. Redox Signal. 2: 811-820

7. Ichijo $H$, Nishida E, Irie K, ten Dijke $P$, Saitoh M, Moriguchi T, Takagi M, Matsumoto K, Miyazono K and Gotoh Y (1997) Induction of apoptosis by ASK1, a mammalian MAPKKK that activates SAPK/JNK and p38 signaling pathways. Science 275: 90-94

8. Song JJ and Lee YJ (2003) Differential role of glutaredoxin and thioredoxin in metabolic oxidative stress-induced activation of apoptosis signal-regulating kinase 1. Biochem. J. 373: 845-853

9. Song JJ and Lee YJ (2003) Role of the ASK1-SEK1-JNK1-HIPK1 signal in Daxx trafficking and ASK1 oligomerization. J. Biol. Chem. 278: 47245-47252

10. Daily D, Vlamis-Gardikas A, Offen D, Mittelman L, Melamed E, Holmgren A and Barzilai A (2001) Glutaredoxin protects cerebellar granule neurons from dopamine-induced apoptosis by dual activation of the ras-phosphoinositide 3-kinase and jun n-terminal kinase pathways. J. Biol. Chem. 276: 21618-21626

11. Lovell MA, Xie C, Gabbita SP and Markesbery WR (2000) Decreased thioredoxin and increased thioredoxin reductase levels in Alzheimer's disease brain. Free Radic. Biol. Med. 28: 418-427

12. Kadowaki H, Nishitoh H, Urano F, Sadamitsu C, Matsuzawa A, Takeda K, Masutani H, Yodoi J, Urano Y, Nagano T and Ichijo H (2005) Amyloid beta induces neuronal cell death through ROS-mediated ASK1 activation. Cell Death Differ. 12: 19-24

13. Ginsberg SD, Hemby SE, Lee VM, Eberwine JH and Trojanowski JQ (2000) Expression profile of transcripts in Alzheimer's disease tangle-bearing CA1 neurons. Ann. Neurol. 48: 77-87

14. Asahina M, Yamada T, Yoshiyama Y and Yodoi J (1998) Expression of adult $T$ cell leukemia-derived factor in human brain and peripheral nerve tissues. Dement. Geriatr. Cogn. Disord. 9: 181-185

15. Esiri M and Oppenheimer DR (1996) In Oppenheimer's Diagnostic Neuropathology: a Practical Manual (Oxford: Blackwell Science) pp. 51-77

16. Beach TG, Walker R and McGeer EG (1989) Patterns of gliosis in Alzheimer's disease and aging cerebrum. Glia 2: 420-436

17. Galvan V, Logvinova A, Sperandio S, Ichijo H and Bredesen DE (2003) Type 1 insulin-like growth factor receptor (IGF-IR) signaling inhibits apoptosis signalregulating kinase 1 (ASK1). J. Biol. Chem. 278: 13325-13332

18. Wei W, Wang $X$ and Kusiak JW (2002) Signaling events in amyloid beta-peptide-induced neuronal death and insulin-like growth factor I protection. J. Biol. Chem. 277: 17649-17656

19. Lovell MA, Ehmann WD, Butler SM and Markesbery WR (1995) Elevated thiobarbituric acid-reactive substances and antioxidant enzyme activity in the brain in Alzheimer's disease. Neurology 45: 1594-1601 
20. Marcus DL, Thomas C, Rodriguez C, Simberkoff K, Tsai JS, Strafaci JA and Freedman ML (1998) Increased peroxidation and reduced antioxidant enzyme activity in Alzheimer's disease. Exp. Neurol. 150: 40-44

21. Lippoldt A, Padilla CA, Gerst H, Andbjer B, Richter E, Holmgren A and Fuxe K (1995) Localization of thioredoxin in the rat brain and functional implications. J. Neurosci. 15: 6747-6756

22. Grant CM (2001) Role of the glutathione/glutaredoxin and thioredoxin systems in yeast growth and response to stress conditions. Mol. Microbiol. 39: 533-541

23. Yamagata K, Tagami M, Ikeda K, Yamori $Y$ and Nara $Y$ (2000) Altered gene expressions during hypoxia and reoxygenation in cortical neurons isolated from stroke-prone spontaneously hypertensive rats. Neurosci. Lett. 284: 131-134

24. Hirota K, Matsui M, Murata M, Takashima Y, Cheng FS, Itoh T, Fukuda K and Yodoi $J(2000)$ Nucleoredoxin, glutaredoxin, and thioredoxin differentially regulate NF-kappaB, AP-1, and CREB activation in HEK293 cells. Biochem. Biophys. Res. Commun. 274: 177-182

25. Saitoh M, Nishitoh H, Fujii M, Takeda K, Tobiume K, Sawada Y, Kawabata M, Miyazono K and Ichijo H (1998) Mammalian thioredoxin is a direct inhibitor of apoptosis signal-regulating kinase (ASK) 1. EMBO J. 17: 2596-2606

26. Miranda-Vizuete A, Rodriguez-Ariza A, Toribio F, Holmgren A, Lopez-Barea J and Pueyo C (1996) The levels of ribonucleotide reductase, thioredoxin, glutaredoxin 1, and GSH are balanced in Escherichia coli K12. J. Biol. Chem. 271: 19099-19103

27. Garrido EO and Grant CM (2002) Role of thioredoxins in the response of Saccharomyces cerevisiae to oxidative stress induced by hydroperoxides. Mol. Microbiol. 43: 993-1003

28. Ramassamy C, Averill D, Beffert U, Bastianetto S, Theroux L, Lussier-Cacan S Cohn JS, Christen Y, Davignon J, Quirion R and Poirier J (1999) Oxidative damage and protection by antioxidants in the frontal cortex of Alzheimer's disease is related to the apolipoprotein E genotype. Free Radic. Biol. Med. 27: $544-553$

29. Cardoso SM and Oliveira CR (2003) Glutathione cycle impairment mediates A beta-induced cell toxicity. Free Radic. Res. 37: 241-250
30. Chang HY, Nishitoh $\mathrm{H}$, Yang X, Ichijo $\mathrm{H}$ and Baltimore D (1998) Activation of apoptosis signal-regulating kinase 1 (ASK1) by the adapter protein Daxx. Science 281: 1860-1863

31. Tobiume K, Matsuzawa A, Takahashi T, Nishitoh H, Morita K, Takeda K, Minowa O, Miyazono K, Noda T and Ichijo H (2001) ASK1 is required for sustained activations of JNK/p38 MAP kinases and apoptosis. EMBO Rep. 2: 222-228

32. Kim AH, Khursigara G, Sun X, Franke TF and Chao MV (2001) Akt phosphorylates and negatively regulates apoptosis signal-regulating kinase 1. Mol. Cell. Biol. 21: 893-901

33. Kenchappa RS, Diwakar L, Boyd MR and Ravindranath V (2002) Thioltransferase (glutaredoxin) mediates recovery of motor neurons from excitotoxic mitochondrial injury. J. Neurosci. 22: 8402-8410

34. Takagi Y, Mitsui A, Nishiyama A, Nozaki K, Sono H, Gon Y, Hashimoto N and Yodoi J (1999) Overexpression of thioredoxin in transgenic mice attenuates focal ischemic brain damage. Proc. Natl. Acad. Sci. U.S.A. 96: 4131-4136

35. Cedazo-Minguez A, Popescu BO, Blanco-Millan JM, Akterin S, Pei JJ, Winblad $B$ and Cowburn RF (2003) Apolipoprotein E and beta-amyloid (1-42) regulation of glycogen synthase kinase-3beta. J. Neurochem. 87: 1152-1164

36. Ferrari A, Hoerndli F, Baechi T, Nitsch RM and Gotz J (2003) Beta-amyloid induces paired helical filament-like tau filaments in tissue culture. J. Biol. Chem. 278: 40162-40168

37. Mirra SS, Heyman A, McKeel D, Sumi SM, Crain BJ, Brownlee LM, Vogel FS, Hughes JP, van Belle G and Berg L (1991) The Consortium to Establish a Registry for Alzheimer's Disease (CERAD). Part II. Standardization of the neuropathologic assessment of Alzheimer's disease. Neurology 41: 479-486

38. Simic G, Kostovic I, Winblad B and Bogdanovic N (1997) Volume and number of neurons of the human hippocampal formation in normal aging and Alzheimer's disease. J. Comp. Neurol. 379: 482-494

39. Trotter EW and Grant CM (2003) Non-reciprocal regulation of the redox state of the glutathione-glutaredoxin and thioredoxin systems. EMBO Rep. 4: 184-188

40. Johansson LH and Borg LA (1988) A spectrophotometric method for determination of catalase activity in small tissue samples. Anal. Biochem. 174: $331-336$ 